\title{
SUBCHRONIC TOXIC EFFECTS OF DI-ETHYLHEXYL PHTHALATE ON OVARY AND TESTIS OF ADULT ALBINO RATS
}

\author{
Haidy M. Fakher, MSc*, Mohammed K. Ahmed, M.D.*, Ola G. Haggag, M.D *, \\ Abdelmonem G. Madboly, M.D.*, and Rasha M. Abdrhabu M.D. ** \\ *Forensic Medicine \& Clinical Toxicology Department; **Pathology Department, \\ Faculty of Medicine, Benha University, Egypt
}

\begin{abstract}
Di-ethylhexyl phthalate (DEHP) -a common type of phthalate plasticizers- has become a major environmental toxic hazard to human health especially the reproductive system. This work aimed to assess the subchronic toxic effects of DEHP on adult albino rats' reproductive organs (ovary and testis) using body \& reproductive organs weight parameter, combined with biochemical, histopathological and immunohistochemical methods. Forty adult male $\&$ female albino rats were divided as follows: male control groups ( 10 rats $=$ " 5 negative \& 5 positive"); female control groups (10 rats= "5 negative $\& 5$ positive"); male DEHP-treated group (10 rats) and female DEHP-treated group (10 rats), both were given DEHP dissolved in corn oil at a dose of $3 \mathrm{gm} / \mathrm{kg}$ once daily for 4 weeks. The results of present study revealed the followings: a decrease in body weight and reproductive organs' weights (ovary and testis); hormonal disruption effects (decrease estrogen "estradiol" \& testosterone serum levels in females \& males respectively); histopathological and immunohistochemical changes in ovary and testis in DEHP-treated groups as compared to control groups. In conclusion, oral exposure of adult albino rats to DEHP at a dose of $3 \mathrm{~g} / \mathrm{kg}$ daily for 4 weeks resulted in toxic hazards to male \& female reproductive organs (ovary and testis).
\end{abstract}

Keywords: Di-Ethylhexyl Phthalate, Ovary, Testis, Reproductive.

INTRODUCTION

Phthalates are substances commonly used as plasticizers. Every year massive amounts of them are manufactured through the world, and they can exist in many consumer products (Muczynski et al., 2012).

Di-ethylhexyl phthalate (DEHP) constitutes the chief type of phthalates and it is considered as a major environmental toxic hazard (Liu et al., 2017).

It is widely used in plastic bags, building substances, toys, food stuffs, personal care products and medical instruments (Schoeters et al., 2008 \& Zhang et al., 2016).

Di-ethylhexyl phthalate can enter human body and hence causes its toxic hazards via several routes like ingestion; inhalation and also through intact skin (Ji et al., 2014).

Di-ethylhexyl phthalate can induce many endocrine and reproductive disorders in males such as testicular injury, infertility, and diminishing of sperm motility. Its exposure may also result in cryptorchidism and hypospadias (Kabir et al., 2015).

Furthermore, female exposure to DEHP can produce many reproductive toxic complications with the ovary being the most affected organ (Martino-Andrade and Chahoud, 2010). 


\section{AIM OF THE WORK}

This work aimed to assess the subchronic toxic effects of di-ethylhexyl phthalate (DEHP) on adult albino rats' reproductive organs (ovary and testis) using body and reproductive organs weight parameter, combined with biochemical, histopathological and immunohistochemical methods.

\section{MATERIAL \& METHODS}

\section{I-material:}

A- Chemicals: all were purchased from Sigma-Aldrich (USA)

- Di-ethylhexyl phthalate (DEHP) as a liquid of purity $\pm 99 \%$ (CAS number $117-81-7$ ).

- Corn oil as a liquid of purity $\pm 99 \%$ (CAS number 8001-30-7).

\section{B- Animals:}

Forty adult male \& female Wistar albino rats, weighing between $180 \mathrm{~g}$ and $200 \mathrm{~g}$ at the beginning of the experiment were included in this study. Rats were allowed for adaptation (1 week before experiments) at Anatomy Department, Faculty of Medicine, Benha University, to ascertain their physical wellbeing, and to exclude any diseased animals. All animals were received the same diet (wheat, bread \& milk) on a schedule of 12 hours of light and 12 hours of dark. The time of DEHP administration was fixed for all animals at 12 P.M.

Experimental design and animal grouping: rats):

Group (A) male control (10 male

- Subgroup A1 (negative control group) 5 male rats: lifted without intervention to measure the basic parameters, with free access to food and water for 4 weeks.

- Subgroup A2 (positive control group) 5 male rats: each rat received 1 $\mathrm{ml} /$ day of corn oil by oral gavage for 4 weeks according to Takai et al. (2009).

Group (B) female control (10 female rats):

- Subgroup B1 (negative control group) 5 female rats: lifted without intervention to measure the basic parameters, with free access to food and water for 4 weeks.

- Subgroup B2 (positive control group) 5 female rats: each rat received 1 $\mathrm{ml} /$ day of corn oil by oral gavage for 4 weeks according to Takai et al. (2009).

Group (C) DEHP male treated group (10 male rats):

- Di-ethylhexyl phthalate was dissolved in corn oil and given to male rats by oral gavage at a dose of $3 \mathrm{gm} / \mathrm{kg}$ once daily for 4 weeks according to Takai et al. (2009).

Group (D) DEHP female treated group (10 female rats):

- Di-ethylhexyl phthalate was dissolved in corn oil and given to female rats by oral gavage at a dose of $3 \mathrm{gm} / \mathrm{kg}$ once daily for 4 weeks according to Takai et al. (2009).

C- Dosage regimen and vehicle:

The used dose of DEHP was $3 \mathrm{~g} / \mathrm{kg} /$ day dissolved in corn oil represented about $1 / 10 \mathrm{LD}_{50}$ in rats (Kavlock et al., 2002).

Each rat was received DEHP orally, via appropriate sized metallic cannula dressed with plastic cover (oral gavage) that not exceeds the tip by $2-3 \mathrm{~mm}$ to prevent injury of the esophagus. Each group received its corresponding drug doses daily for 4 weeks then rats were sacrificed after 24 hours from last administrated dose.

This study was accepted by the Research Ethical Board of Faculty of Medicine, Benha University.

\section{II- methods (study parameters):}

A-Weight of the body and reproductive organs (ovary \& testis):

Rats' body weights were measured before treatment, then at the end of each week of the studied four weeks using a 
sensitive balance. Testes and ovaries were removed and stripped from their fatty tissues and blood vessels, after scarification of rats at the end of the $4^{\text {th }}$ week of treatment and their relative weights were measured.

\section{B-Biochemical study (hormonal assay):}

Animals were anesthetized by ether, then they were laid on appropriate device and blood samples were taken from their hearts by $5 \mathrm{ml}$ syringes. Blood samples were put in clean tubes lacking anticoagulant and left at $37^{\circ} \mathrm{C}$ incubator for 15 minutes. After centrifugation of clotted blood, serum samples were put in the special tubes, covered by parafilm, labeled and kept frozen for three days to be tested later for different hormones (Picard et al., 2008).

Serum estrogen (estradiol), testosterone, follicle-stimulating hormone (FSH), luteinizing hormone (LH) levels were estimated using Enzyme Linked Fluorescence Assay (Anckaert et al., 2002), with the commercial kits VIDAS (BIOMERIEUX Company, France) by VIDAS apparatus (BIOMERIEUX Company, France).

\section{C- Histopathological study:}

According to Bancroft and Gamble (2008) testes and ovaries soaked in bouin's solution, which is used to fix organs that need good morphologic analysis like testis and ovary. Tissue specimens were fixed for 6- 8 hours and then transfered to $70 \%$ alcohol before submitting to histology for automated dehydration, paraffin embedding, sectioning and staining at Pathology Department, Faculty of Medicine, Benha University.

D- Immunohistochemical study: Immunohistochemical (IHC) reactions were carried out through the streptavidin/peroxidase method for replicative DNA synthesis using proliferating cell nuclear antigen (PCNA) (Happerfield et al., 1993). Positive reactions appeared brown and strict to the nucleus of the cell.

\section{Statistical analysis:}

The collected data were tabulated and analyzed using SPSS version 16 software (SPSS Inc, Chicago, ILL Company). Quantitative data were expressed as mean \pm standard deviation $( \pm$ SD) and range. They were tested for normality using Shapiro-Wilks test assuming normality $\mathrm{t} P>0.05$. Student ' $\mathrm{t}$ ' test and Mann Whitney $\mathrm{U}\left(\mathrm{Z}_{\mathrm{MwU}}\right)$ test were used to assess difference between parametric and non-parametric variables (respectively). The accepted level of significance in this work was stated at 0.05 ( $\mathrm{P}<0.05$ was considered significant) according to Greenberg et al. (1996).

\section{RESULTS}

The results of both negative and positive control groups [male $\&$ female] did not show any statistically significant differences, so, the data obtained for both groups were expressed in the figures and tables as one group "control".

\section{I-weight of the body and reproductive}

\section{organs:}

This study revealed a nonsignificant ( $p>0.05)$ difference between all male rat groups as regard to body weight before treatment, meanwhile, a non-significant $(\mathrm{p}>0.05)$ decrease in the mean values of body weight of male DEHP-treated group in comparison to control groups was observed after the $1^{\text {st }}$ and the $2^{\text {nd }}$ weeks of treatment, but a highly significant $(\mathrm{p}<0.001)$ decrease in the mean values of body weight of male DEHP-treated group was detected after the $3^{\text {rd }}$ and the $4^{\text {th }}$ weeks of treatment, as illustrated in fig. 1 . 


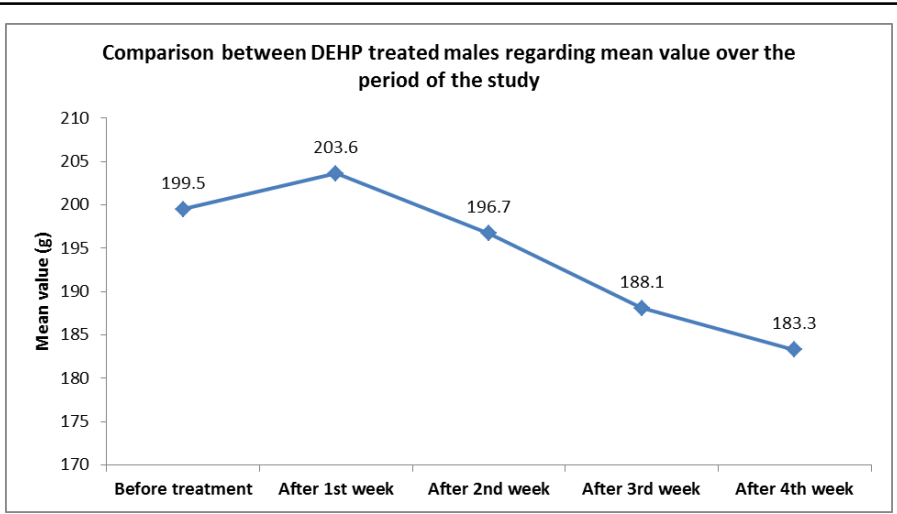

Figure (1): Line graph showing the mean values of body weight of DEHP-treated male rat group over the period of the study $(\mathrm{n} .=10)$.

The present work illustrated a significant $(\mathrm{p}<0.016)$ reduction in the mean values of relative testes weights of

male DEHP-treated group in comparison to control groups at the end of the experiment, as showed in table 1.

Table (1): Comparison between the mean values of relative testes weights among different male rat studied groups $(\mathrm{n}=20,10$ for each)

\begin{tabular}{|c|c|c|c|c|c|}
\hline \multirow{2}{*}{ Male Groups } & \multicolumn{2}{|l|}{ Relative testis weight $(\mathbf{g})$} & \multirow{2}{*}{ P } & \\
\cline { 2 - 4 } & Mean & $\mathbf{\pm S D}$ & Range & & \\
\hline DEHP-treated & 0.965 & 0.052 & $0.899-1.06$ & \multirow{2}{*}{2.64} & $0.016\left(\mathrm{~S}^{*}\right)$ \\
\hline Control & 0.910 & 0.040 & $0.843-0.970$ & & \\
\hline \multicolumn{5}{|r}{ S*: Significant } &
\end{tabular}

The current work illustrated a nonsignificant $(p>0.05)$ difference between the female rat groups as regard body weight before treatment. A nonsignificant $(\mathrm{p}>0.05)$ reduction in the mean values of body weight of female DEHP-treated group was observed after the $1^{\text {st }}$ and the $2^{\text {nd }}$ weeks of treatment in comparison to control groups, meanwhile a significant $(\mathrm{p}<0.05)$ decrease in the mean values of body weight of female DEHP-treated group was detected after the $3^{\text {rd }}$ week of treatment and a highly significant ( $p$ $<0.001)$ decrease in the mean values of body weight was confirmed after the $4^{\text {th }}$ week of treatment, as illustrated in fig. 2.

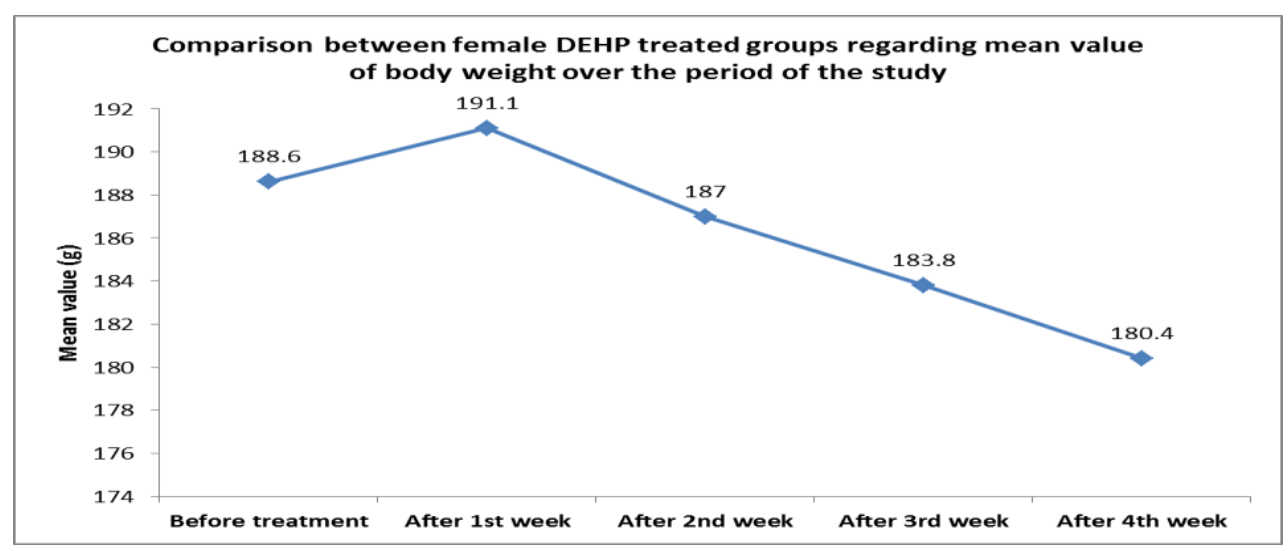

Figure (2): Line graph showing the mean values of body weight of DEHP-treated female rat group over the period of the study $(\mathrm{n}=10)$. 
The current work showed a highly significant $(\mathrm{p}<0.001)$ reduction in the mean values of relative ovary weights of female DEHP-treated group in comparison to control groups at the end of the experiment, as showed in table 2.

Table (2): Comparison between the mean values of relative ovary weights among different female rat studied groups $(n=20,10$ for each)

\begin{tabular}{|c|c|c|c|c|c|}
\hline \multirow{2}{*}{ Female groups } & \multicolumn{3}{|c|}{ Relative ovary weight (g) } & \multirow{2}{*}{$\begin{array}{l}\text { Student } \\
\text { 't' test }\end{array}$} & \multirow{2}{*}{$\mathbf{P}$} \\
\hline & Mean & $\pm \mathbf{S D}$ & Range & & \\
\hline DEHP-treated & 0.017 & 0.003 & $0.01-0.023$ & \multirow{2}{*}{5.11} & \multirow{2}{*}{$<0.001\left(\mathrm{HS}^{*}\right)$} \\
\hline Control & 0.025 & 0.002 & $0.021-0.03$ & & \\
\hline
\end{tabular}

\section{HS*: Highly Significant}

II- biochemical study (hormonal assay):

In the present study, DEHP-treated male rats showed a highly significant ( $\mathrm{p}$ $<0.001$ ) decrease in the mean values of testosterone level as compared to control groups, and a non-significant ( $\mathrm{p}$ $>0.05$ ) increase in the mean values of FSH and LH levels in DEHP-treated male group as compared to control groups, as showed in table 3 .

Table (3): Comparison between different male rat studied groups regarding the mean values of testosterone, follicle-stimulating hormone (FSH) and luteinizing hormone ( $\mathrm{LH})$ levels $(\mathrm{n}=20,10$ for each):

\begin{tabular}{|c|c|c|c|c|c|c|}
\hline $\begin{array}{l}\text { Studied } \\
\text { hormone }(\mathrm{ng} / \mathrm{ml})\end{array}$ & Male groups & Mean & $\pm \mathbf{S D}$ & Range & $\begin{array}{l}\text { Student } \\
\text { 't' test }\end{array}$ & $\mathbf{P}$ \\
\hline \multirow[t]{2}{*}{ Testosterone } & DEHP-treated & 1.25 & 0.136 & $1.12-1.48$ & \multirow[t]{2}{*}{$52.7 * *$} & \multirow{2}{*}{$\begin{array}{l}<0.001 \\
\left(\mathbf{H S}^{*}\right)\end{array}$} \\
\hline & Control & 3.66 & 0.047 & $3.61-3.75$ & & \\
\hline \multirow[t]{2}{*}{ FSH } & DEHP-treated & 0.445 & 0.073 & $0.32-0.53$ & \multirow[t]{2}{*}{$0.98 * *$} & \multirow{2}{*}{$\begin{array}{l}\mathbf{0 . 3 2} \\
\left(\mathbf{N S}^{*}\right)\end{array}$} \\
\hline & Control & 0.412 & 0.081 & $0.33-0.6$ & & \\
\hline \multirow[t]{2}{*}{$\mathbf{L H}$} & DEHP-treated & 1.525 & 0.072 & $1.45-1.60$ & \multirow[t]{2}{*}{$1.33 * *$} & \multirow{2}{*}{$\begin{array}{l}0.18 \\
\left(N^{*} *\right)\end{array}$} \\
\hline & Control & 1.478 & 0.063 & $1.32-1.57$ & & \\
\hline
\end{tabular}

HS*: Highly Significant; NS*: Non-Significant.

**"Z" value of Mann Whitney U ( $\left.\mathbf{Z}_{\mathbf{M w U}}\right)$ test was used

At the same time, the DEHP-treated female rats showed a highly significant $(p<0.001)$ decrease in the mean value of estrogen (estradiol) level as compared to control groups and showed a nonsignificant $(\mathrm{p}>0.05)$ increase in the mean values of FSH and LH levels in DEHP female treated group in comparison to control groups, as illustrated in table 4.

Table (4): Comparison between different female rat studied groups regarding the mean values of estrogen (estradiol), follicle-stimulating hormone (FSH) and luteinizing hormone ( $\mathrm{LH})$ levels $(\mathrm{n}=20,10$ for each):

\begin{tabular}{|c|c|c|c|c|c|c|}
\hline \begin{tabular}{|c|} 
Studied hormone \\
$(\mathrm{ng} / \mathrm{ml})$
\end{tabular} & Female groups & Mean & $\pm \mathbf{S D}$ & Range & \begin{tabular}{|l|} 
Student \\
''t' test \\
\end{tabular} & $\mathbf{P}$ \\
\hline \multirow{2}{*}{$\begin{array}{c}\text { Estrogen } \\
\text { (estradiol) }\end{array}$} & DEHP treated & 20.90 & 0.875 & $20-22$ & \multirow{2}{*}{$3.81 * *$} & \multirow{2}{*}{$\begin{array}{l}<0.001 \\
\left(\text { HS }^{*}\right) \\
\end{array}$} \\
\hline & Control & 31.50 & 2.321 & $29-35$ & & \\
\hline \multirow{2}{*}{ FSH } & DEHP treated & 2.09 & 0.29 & $1.95-2.9$ & \multirow{2}{*}{$1.68 * *$} & \multirow{2}{*}{$\begin{array}{l}0.092 \\
\left(\mathrm{NS}^{*}\right)\end{array}$} \\
\hline & Control & 1.95 & 0.04 & $1.88-2.02$ & & \\
\hline \multirow{2}{*}{$\mathbf{L H}$} & DEHP treated & 2.440 & 0.043 & $2.40-2.49$ & \multirow{2}{*}{$1.41 * *$} & \multirow{2}{*}{$\begin{array}{c}0.15 \\
\left(\mathbf{N S}^{*}\right)\end{array}$} \\
\hline & Control & 2.405 & 0.033 & $2.34-2.46$ & & \\
\hline
\end{tabular}

HS*: Highly Significant; NS*: Non-Significant.**"Z" value of Mann Whitney U (ZMWU) test was used 
III- histopathological study:

The biochemical findings were associated with histopathological changes in the testicular and ovarian tissues stained by hematoxylin and eosin stains. These changes were in the form of seminiferous tubules of variable sizes \& shapes, degenerated germinal layers, and vacuolations in the stroma between seminiferous tubules, as compared to normal structure of testes of control rats, as illustrated in fig. 3-5.

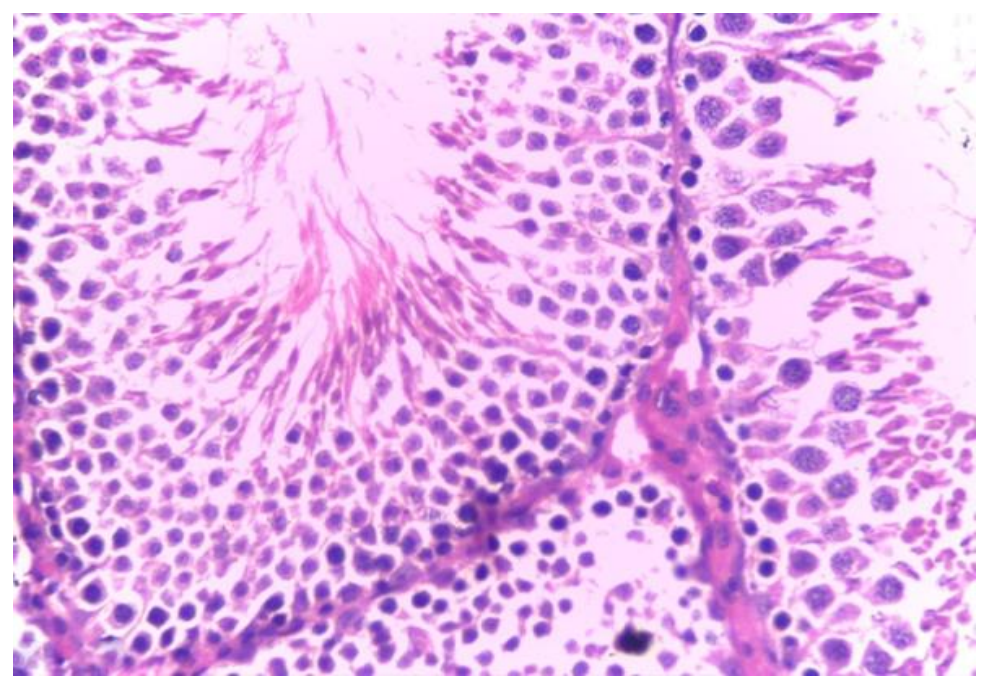

Figure (3): Photomicrograph of a section in rat's testis prepared from a control rat showing normal architecture with well-arranged seminiferous tubule and normal interstitial tissues (H\&E x 400).

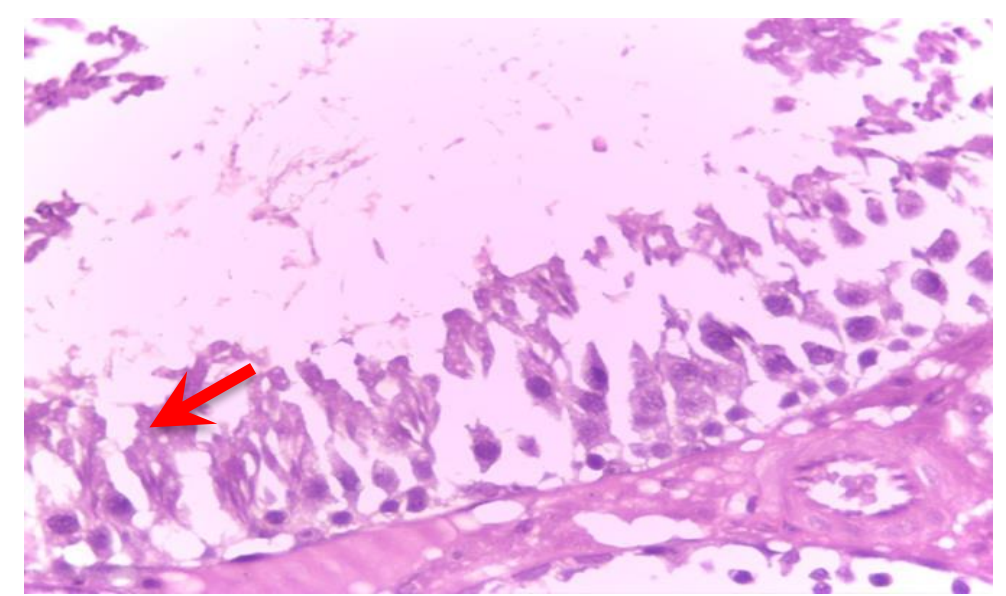

Figure (4): Photomicrograph of a section in rat's testis prepared from a DEHP-treated rat showing seminiferous tubules variable in sizes \& shapes with degenerated germinal layers (red arrow) (H\&E x 400). 


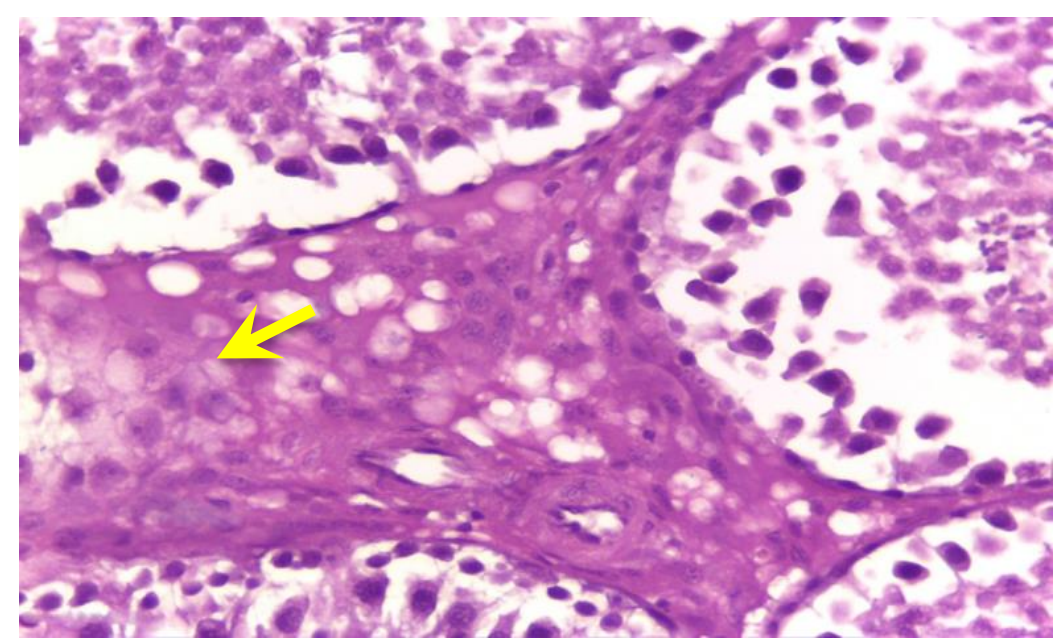

Figure (5): Photomicrograph of a section in rat's testis prepared from a DEHP-treated rat showing degenerated spermatocytes (red arrow) \& vacuolations (yellow arrow) (H\&E x 400).

In the ovarian tissues, there were degenerations in the follicular cells with vacuolations in the stroma in DEHP-

treated female rats, as compared to normal structure of ovaries in female

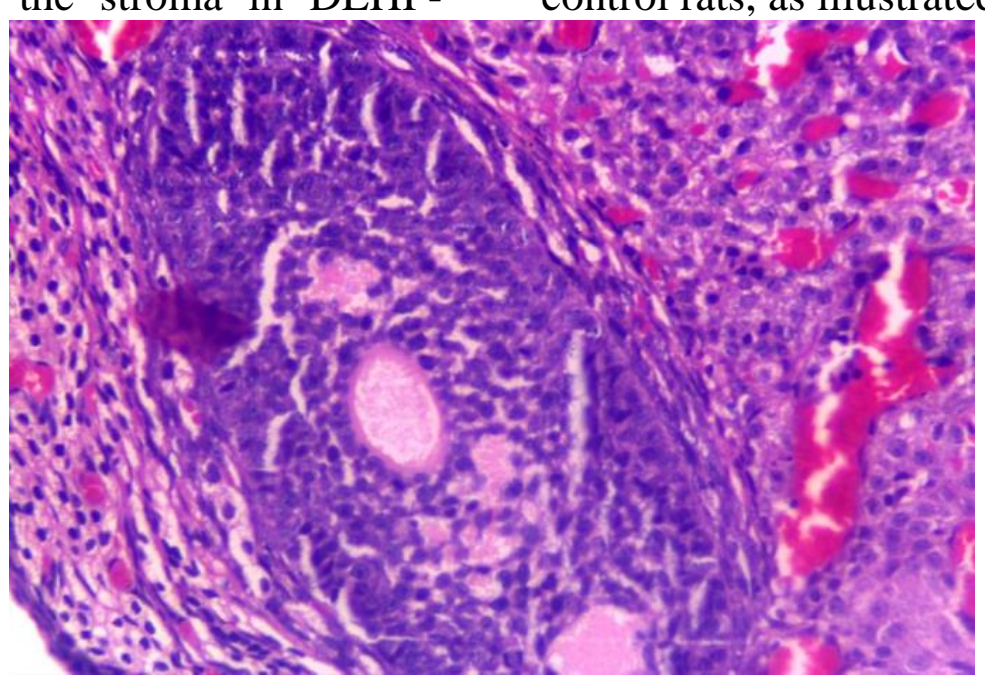

Figure (6): Photomicrograph of a section in rat's ovary prepared from a control rat showing normal architecture with well-arranged follicular cells (H\&E x 400).

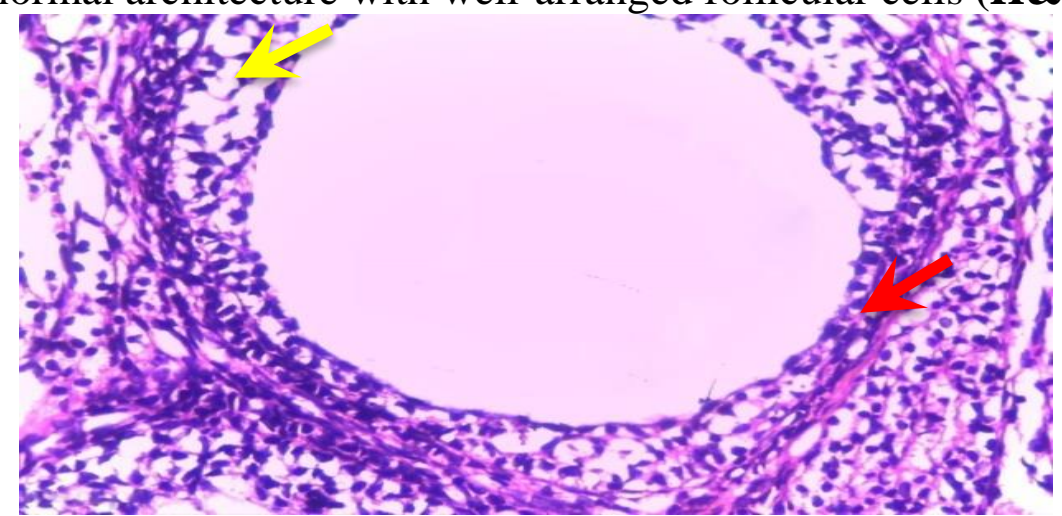

Figure (7): Photomicrograph of a section in rat's ovary prepared from a DEHP-treated rat showing degenerated follicular cells (red arrow) with vacuolations in the stroma (yellow arrow) $(\mathbf{H \& E} \mathbf{x} \mathbf{4 0 0})$. 
IV- IMMUNOHISTOCHEMICAL STUDY:

Testicular sections of DEHP-treated male group showed a strong expression of nuclear PCNA staining seen only in spermatogonia layer and a weak expression in primary spermatocyte and secondary spermatocyte, indicating suppression of germ cell proliferation, as compared to control rats which showed a strong expression of nuclear PCNA staining in all germinal layers (spermatogonia, primary spermatocyte and secondary spermatocyte), as illustrated in fig. 9-10.

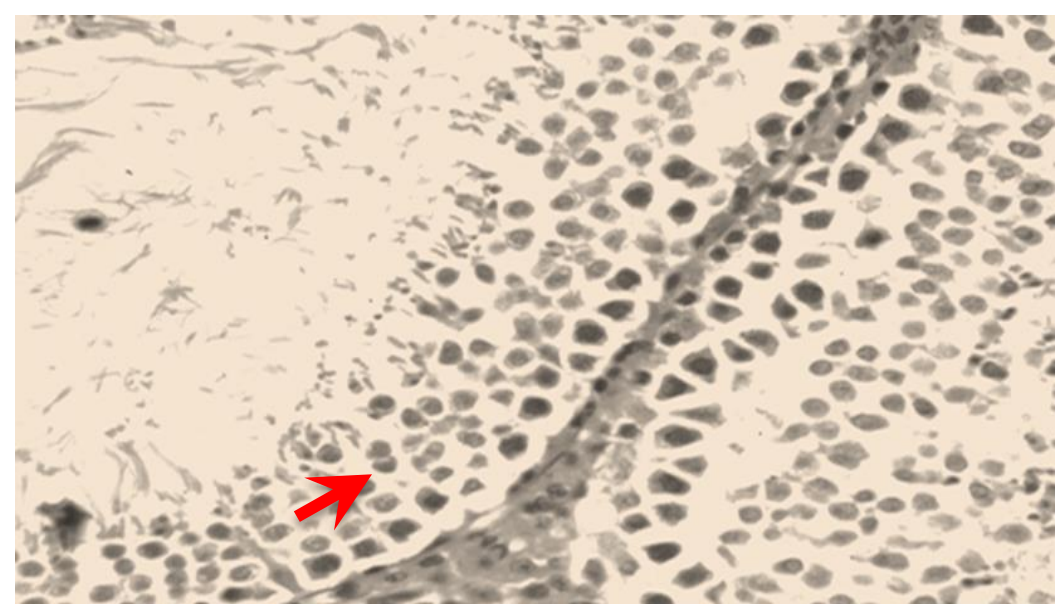

Figure (9): Photomicrograph of a section in rat's testis prepared from a control rat showing seminiferous tubule with strong expression of nuclear PCNA staining in all germinal layers (spermatogonia, primary spermatocyte and secondary spermatocyte) with regular sizes of seminiferous tubules (red arrow) (IHC x 400).

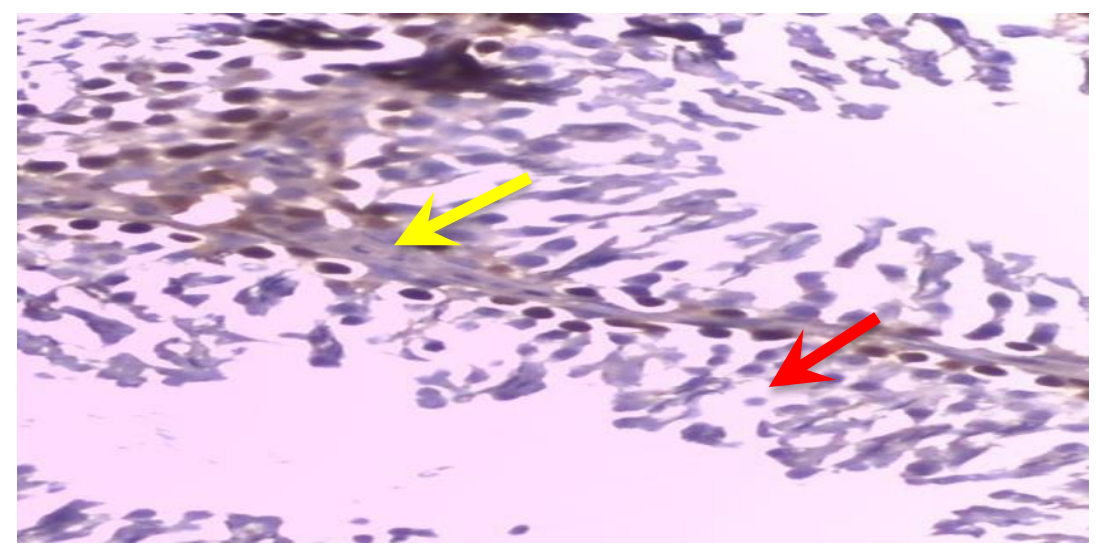

Figure (10): Photomicrograph of a section in rat's testis prepared from a DEHPtreated rat showing strong expression of nuclear PCNA staining in only spermatogonia layer (red arrow) and weak expression in primary spermatocyte and secondary spermatocyte (yellow arrow) with irregular sizes of seminiferous tubules (IHC x 400).

The present work showed a weak expression of nuclear PCNA staining in follicular cells and stromal cells in ovarian sections of DEHP-treated female group, as compared to control rats which showed a strong expression of nuclear PCNA staining in follicular cells and weak expression in the stromal cells of ovarian sections, as illustrated in fig. 11-12. 


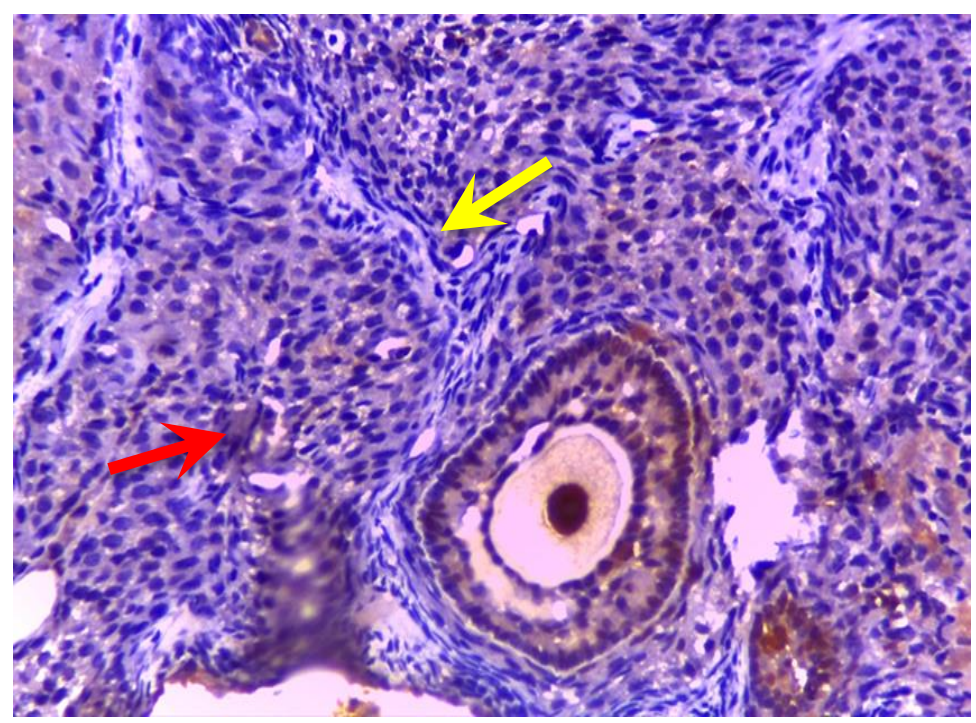

Figure (11): Photomicrograph of a section in rat's ovary prepared from a control rat showing a strong expression of nuclear PCNA staining in follicular cells (red arrow) and a weak expression in the stromal cells (yellow arrow) (IHC x 400).

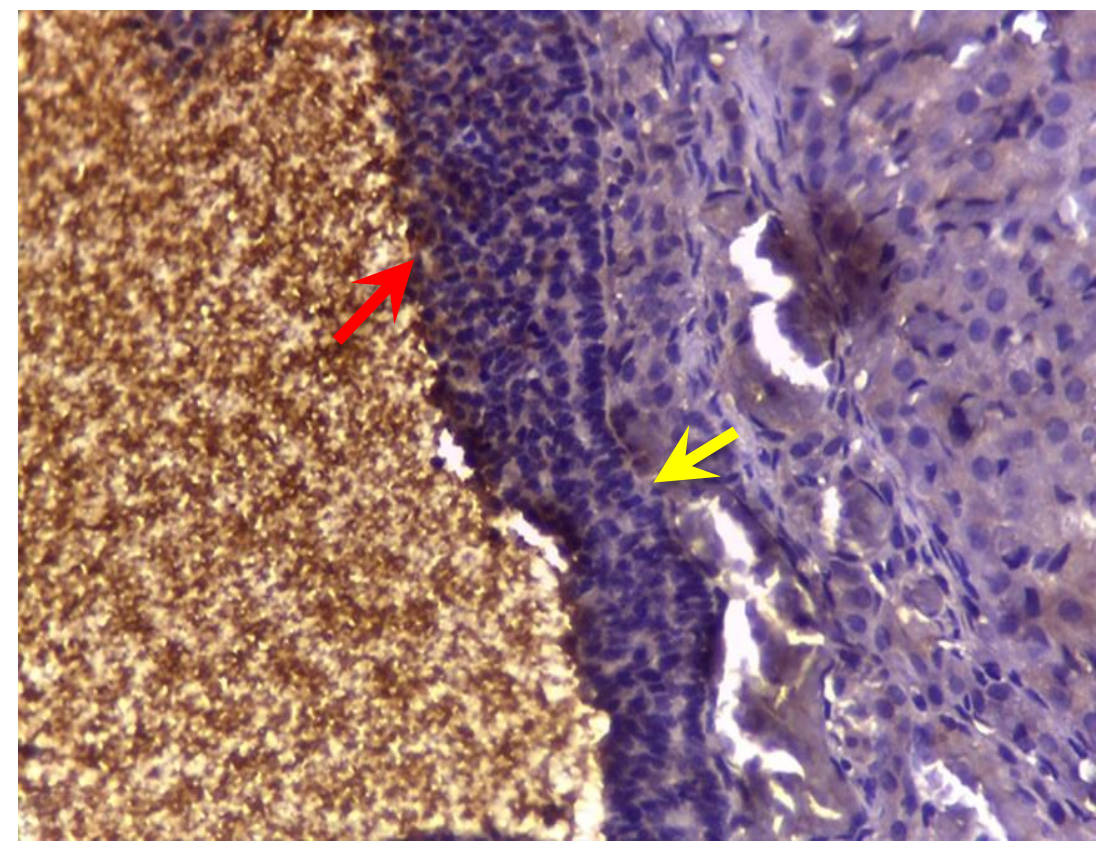

Figure (12): Photomicrograph of a section in rat's ovary prepared from a DEHPtreated rat showing weak expression of nuclear PCNA staining in follicular cells (red arrow) and stromal cells (yellow arrow) (IHC x 400).

\section{DISCUSSION}

Di-ethylhexyl phthalate (DEHP) is considered as a toxic hazard and can produce several endocrine and reproductive disorders in rodents (Liu et al., 2017).

As a result of its prevalent and widespread use, DEHP can be found in water, food products, air, soil, plants and animals (Latini et al., 2006).

The present study revealed that the body weight mean values of DEHPtreated rats either in male or female groups decreased as compared to control groups, which was nonsignificant after the $1^{\text {st }}$ and the $2^{\text {nd }}$ weeks, and became highly significant 
after the $3^{\text {rd }}$ and the $4^{\text {th }}$ weeks of treatment.

Liu et al. (2014) showed that DEHP oral exposure at a dose of 1000 or $3000 \mathrm{mg} / \mathrm{kg}$ resulted in a nonsignificant difference in the mean body weights of rats by the $1^{\text {st }}$ week. But after the $2^{\text {nd }}, 3^{\text {rd }}$, and $4^{\text {th }}$ weeks, their weights were significantly decreased as compared with the control rats.

Erkekoglu et al. (2011) concluded that rates treated with $1000 \mathrm{mg} / \mathrm{kg}$ of DEHP by oral gavage exhibited a significant reduction in body weights after 10 days of DEHP exposure.

On the other hand, Somasundaram et al. (2017) detected no changes in the body weight of adult female rats exposed to oral doses (1, 10 , and $100 \mathrm{mg} / \mathrm{kg}$ daily) of DEHP for 30 days.

Body weight may be considered as a useful marker that inclusively reflects the toxic effects of DEHP on the growth status of rats. DEHP can decrease the body weight gain by disturbing fat metabolism and synthesis (Itsuki-Yoneda et al., 2007).

The current study showed a significant decrease in relative testis and ovary weights in DEHP-treated rat groups as compared to control rat groups.

The results of the present study were in agreement with the study of Helal (2014) who reported a statistically significant testicular weight reduction in male rats treated with DEHP at a dose of $1000 \mathrm{mg} / \mathrm{kg}$ body weight.

Meanwhile, Grande et al. (2007) found that exposure to DEHP in female rats did not show any change in ovary weight.

In the present study and as regard to hormonal assay; a significant decrease in serum testosterone levels was detected, and a non-significant decrease in serum follicle-stimulating hormone $(\mathrm{FSH}) \&$ luteinizing hormone (LH) levels were observed in DEHPtreated male groups as compared to control male groups.

These findings were in a harmony with those of Gao et al. (2014) who showed a significant decrease in testosterone levels in male rats treated with DEHP.

Noriega et al. (2009) detected a highly significant decrease in serum testosterone level with large dose of DEHP. They explained that due to the inhibitory effects of phthalates on pubertal development especially on testis.

Zhang et al. (2014) concluded that DEHP decreased testosterone production through activation of oxidative stress. In this study, DEHP was administrated orally to prepubertal male rats, from postnatal day 22 to day35.

Savchuk et al. (2015) stated that mono (2-ethylhexyl) phthalate (MEHP) -a main DEHP metabolitedecreases LH/human chorionic gonadotropin stimulated androgen production by isolated rat Leydig cells.

The current study illustrated that there was a highly significant decrease in serum estrogen (estradiol) levels and a non-significant decrease in serum FSH and LH levels in DEHP-treated female rats, compared to control female rats.

Liu et al. (2014) showed that DEHP exposure via oral gavage at a dose of $1000-3000 \mathrm{mg} / \mathrm{kg} /$ day significantly decreased serum estrogen (estradiol) levels in adult female rats.

Hirosawa et al. (2006) detected that serum estrogen (estradiol), FSH and LH levels were reduced after DEHP exposure in female rats. 
Lovekamp-Swan and Davis (2003) stated that MEHP inhibits estrogen (estradiol) synthesis through lowering the mRNA, protein levels and the activity of aromatase.

The results of the present study showed histopathological changes in the testicular specimens of the DEHPtreated male rats, including dilatation in seminiferous tubules, edematous stroma with vacuolations and degenerated spermatocytes.

These results were in agreement with the study of Abd-Ellah et al. (2016) who observed histopathological changes of DEHP-treated male rats in the form of degeneration and necrosis of spermatogonial cells, combined with azoospermia.

Also, Kitaoka et al. (2013) reported that DEHP exposure in adult male mice showed germ cell sloughing of seminiferous tubules intermixed with normal seminiferous tubules at 4 weeks, while significant spermatogenic disorders occurred after 8 weeks of treatment.

Abdel-Kawi et al. (2016) observed distorted seminiferous tubules, associated with abundant vacuoles in some tubules, reduction in the thickness of the germinal epithelium and sloughed germ cells in DEHP-treated male rats.

Another study detected hyperplasia and clustering of Leydig cells after doses of $938 \mathrm{mg} / \mathrm{kg} /$ day of DEHP in Sprague-Dawley rats (Culty et al., 2008).

Alam et al. (2010) detected that vacuolation is the first microscopic sign of testicular injury followed by ultrastructural alterations in sertoli cells produced by DEHP exposure.

Also Zhao et al. (2012) concluded that the main DEHP metabolite (MEHP) adversely affects the steroidogenesis in rat Leydig cells by stimulating reactive oxygen species (ROS) production.

The results of the present study also showed histopathological changes in the ovarian specimens of the female rats treated with DEHP in the form of degenerated follicular cells with vacuolation in the stroma.

These results were consistent with those of Takai et al. (2009) who observed vacuolations of stromal cells in the female rats receiving $300 \mathrm{mg} / \mathrm{kg}$ or more of DEHP and an increase of large atretic follicles in groups at doses of 1,000 and $3000 \mathrm{mg} / \mathrm{kg}$.

Female rats exposed to DEHP resulted in a reduction in numbers of growing follicles (primary, secondary and antral follicles), and increased irregularity of estrous cycles and granulosa cell apoptosis (Xu et al., 2010).

Assessing of DEHP toxic effects by combined histopathological and immunohistochemical studies on the reproductive organs (testis and ovary) is a valuable indicator of DEHP toxicity (Sanbuissho et al., 2009).

Regarding Immunohistochemical study on testicular sections of DEHPtreated male group, the present study revealed a strong expression of nuclear PCNA staining in only spermatogonia layer and a weak expression in primary $\&$ secondary spermatocytes.

These findings were in a harmony with those of Salama et al. (2013) who reported that phthalate exposure in adult male rats for 4 weeks showed a positive (strong) reaction for PCNA in the nuclei of spermatogonia, and a negative (weak) reaction for PCNA in the nuclei of primary spermatocytes and early spermatids.

Li et al. (2014) reported that DEHP produced anti-proliferative 
effects on testicular germ cells, and caused atrophy of testes by germ cell apoptosis.

Di-ethylhexyl phthalate could induce mitochondrial injury and ROS overproduction which may result in apoptosis of spermatocytes (Kasahara et al., 2002).

Regarding immunohistochemical study of ovarian sections of DEHPtreated female rats, the present study showed a weak expression of nuclear PCNA staining in follicular cells and stromal cells.

The results of this study were consistent with those of Takai et al. (2009) who observed large atretic follicles with weak PCNA immunohistochemical staining in follicular cells, in female rats treated with DEHP.

Hannon and Flaws (2015) stated that phthalates can impair ovarian/oocyte development, follicular growth and ovarian maturation and ovulation.

Phthalates can result in free radicals production which is suggested to induce many pathologic disturbances in the reproductive system (Rusyn et al., 2006).

\section{CONCLUSION}

It can be concluded that oral exposure of adult Wistar albino rats to di-ethylhexyl phthalate (DEHP) at a dose of $3 \mathrm{~g} / \mathrm{kg}$ body weight /day for 4 weeks resulted in:

- A decrease in body weight and reproductive organs' weights (ovary and testis).

- Hormonal disruption effects, i.e., a decrease in testosterone and estrogen "estradiol" serum levels in male and female adult albino rats respectively.

- Histopathological and immunohistochemical changes in the reproductive organs of both sexes (ovary and testis).

\section{RECOMMENDATIONS}

1. Comprehensive awareness of general population to the toxic hazards of DEHP on human health, especially the reproductive system.

2. Minimize the environmental exposure of DEHP to maintain the normal reproductive functions.

3. Finally, the use of other alternative materials to DEHP that have either no or minimal toxic effects should be encouraged.

\section{ACKNOWLEDGMENT}

Our deep gratitude to all staff members of the Forensic Medicine and Clinical Toxicology Department, Faculty of Medicine, Benha University, for their help and cooperation.

http://www.fmed.bu.edu.eg

\section{REFERENCES}

Abdel-Kawi, S.H.; Hashem, K.S. and Abd-Allah, S. (2016): Mechanism of di-ethylhexyl phthalate (DEHP) induced testicular damage and of grape seed extract-induced protection in the rat. Food Chem. Toxicol., 90: 64-75.

Abd-Ellah, M.F.; Aly, H.A.; Mokhlis, H.A. and Abdel-Aziz, A.H. (2016): Quercetin attenuates di-(2-ethylhexyl) phthalateinduced testicular toxicity in adult rats. Hum. Exp. Toxicol., 35 (3): 232-243.

Alam, M.S.; Andrina, B.B.; Tay, T.W.; Tsunekawa, N.; Kanai, Y. and Kurohmaru, M. (2010): Single administration of di (nbutyl) phthalate delays spermatogenesis in prepubertal 
rats. Tissue Cell, 42: 129-135.

Anckaert, E.; Mees, M.; Schiettecatte, J. and Smitz, J. (2002): Clinical validation of a fully automated $17 \beta$-estradiol and progesterone assay (VIDAS®) for use in monitoring assisted reproduction treatment. Clin. Chem. Lab. Med.; 40 (8): 824-831

Bancroft, J.D. and Gamble, M. (eds.) (2008): Fixatives. In: Theory and Practice of Histology Techniques. Churchill Livingstone, Elsevier, China, $8^{\text {th }}$ ed., chapter (10), pp: 7275.

Culty, M.; Thuillier, R.; Li, W.; Wang, Y.; Martinez-Arguelles, D.B.; Benjamin, C.G.; Triantafilou, K.M.; Zirkin, B.R. and Papadopoulos, V. (2008): In utero exposure to di (2-ethylhexyl) phthalate exerts both short-term and long-lasting suppressive effects on testosterone production in the rat. Biol. Rep., 78: 10181028.

Erkekoglu, P.; Zeybek, N.D.; Giray, B.; Asan, E.; Arnaud, J. and Hincal, F. (2011): Reproductive toxicity of di (2-ethylhexyl) phthalate in seleniumsupplemented and seleniumdeficient rats. Drug Chem. Toxicol., 34: 379-389.

Gao, L.; Li, X. and Cai, D. (2014): Study on the mechanism of di-2ethylhexyl phthalate and cypermethrin inducing gonadal dysgenesis in the prepubertal male rats. Chinese J. Indust. Hyg. Occup., 32 (3):195-201.

Greenberg, R. S., R. S. Daniels, W. D. Flanders, J. W. Eley, and J. R. Boring (eds.) (1996): Diagnostic Testing. In: Medical Epidemiology. McGraw-Hill, New York, NY, $3^{\text {rd }}$ ed., chapter (4), pp:
77-89.

Hannon, P.R. and Flaws, J.A. (2015): The effects of phthalates on the ovary. Front. Endocrinol., 6: 8.

Happerfield, L.c.; Boborow, L.g.; Bains, R.M. and Miller,K.D.(1993): $\quad$ Peroxidase labeling immunocytochemistry: a comparison of eleven commercially available avidinebiotin systems. J. Histochemist. Cytochemist., 41: 291-302.

Helal, M.A. (2014): Celery oil modulates DEHP-induced reproductive toxicity in male rats. Reprod. Biol., 14 (3): 182-189.

Hirosawa, N.; Yano, K.; Suzuki, Y. and Sakamoto, Y. (2006): Endocrine disrupting effect of di (2-ethylhexyl) phthalate on female rats and proteome analyses of their pituitaries. Proteomics., 6: 958971.

Itsuki-Yoneda, A.; Kimoto, M.; Tsuji, H.; Hiemori, M. and Yamashita, H. (2007): Effect of a hypolipidemic drug, di (2ethylhexyl) phthalate, on mRNAexpression associated fatty acid and acetate metabolism in rat tissues. Biosci. Biotechnol. Biochem., 71: 414-420.

Ji, Y.; Wang, F.; Zhang, L.; Shan, C.; Bai, Z.; Sun, Z.; Liu, L. and Shen, B. (2014): A comprehensive assessment of human exposure to phthalates from environmental media and food in Tianjin, China. J. Hazard Mater., 279: 133-140.

Kabir, E.R.; Rahman, M.S. and Rahman, I. (2015): A review on endocrine disruptors and their possible impacts on human health. Environ. Toxicol. Pharmacol., 40 (1): 241-258.

Kasahara, E.; Sato, E. F.; Miyoshi, 
M.; Konaka, R.; Hiramoto, K.; Sasaki, J.; Tokuda, M.; Nakano, Y. and Inoue, M. (2002): Role of oxidative stress in germ cell apoptosis induced by di (2ethylhexyl) phthalate. Biochem. J., 365 (3): 849-856.

Kavlock, R.; Boekelheide, K.; Chapin, R.; Cunningham, M.; Faustman, E.; Foster, P.; Golub, M.; Henderson, R.; Hinberg, I.; Little, R.; Seed, J.; Shea, K.; Tabacova, S.; Tyl, R.; Williams, P. and Zacharewski, T. (2002): The National Toxicology Program (NTP) center for the evaluation of risks to human reproduction: phthalates expert panel report on the reproductive and developmental toxicity of di-noctyl phthalate. Reprod. Toxicol., 5: 721-734.

Kitaoka, M.; Hirai, S.; Terayama, H.; Naito, N.; Ning, Q.U.; Hatayama, N.; Miyaso, H.; Matsuno, Y.; Komiyama, M.; Itoh, M. and Mori, C. (2013): Effects on the local immunity in the testis by exposure to di-(2ethylhexyl) phthalate (DEHP) in mice. J. Reprod., 59 (5): 485-490.

Latini, G.; Del Vecchio, A.; Massaro, M.; Verrotti, A. and De Felice, C. (2006): Phthalate exposure and male infertility. Toxicol., 226 (2): 90-98.

Liu, J.C.; Lai, F.N.; Li, L.; Sun, X.F.; Cheng, S.F.; Ge, W.; Wang, Y.F.; Li, L.; Zhang, X.F.; De Felici, M.; Dyce, P.W. and Shen, W. (2017): Di (2ethylhexyl) phthalate exposure impairs meiotic progression and DNA damage repair in fetal mouse oocytes in vitro. Cell Death Dis., 3; 8 (8):e2966.

Liu, T.; Li, N.; Zhu, J.; Yu, G.; Guo,
K.; Zhou, L.; Zheng, D.; Qu X.; Huang, J.; Chen, X.; Wang, S. and Ye, L. (2014): Effects of di(2-ethylhexyl) phthalate on the hypothalamus-pituitary-ovarian axis in adult female rats. Reprod. Toxicol., 46: 141-147.

Lovekamp-Swan, T. and Davis, B.J. (2003): Mechanisms of phthalate ester toxicity in the female reproductive system. Environ. Health Perspect., 111: 139-145.

Lv, Z.; Cheng, J.; Huang, S.; Zhang, Y.; Wu, S.; Qiu, Y.; Geng, Y.; Zhang, Q.; Huang, G.; Ma, Q.; Xie, X.; Zhou, S.; Wu, T. and Ke, Y. (2016): DEHP induces obesity and hypothyroidism through both central and peripheral pathways in $\mathrm{C} 3 \mathrm{H} / \mathrm{He}$ mice. Obesity (Silver Spring), 24 (2): 368-378.

Martino-Andrade, A.J. and Chahoud, I. (2010): Reproductive toxicity of phthalate esters. Mol. Nutr. Food Res., 54: 148-157.

Muczynski, V.; Lecureuil, C.; Messiaen, S.; Guerquin, M.J.; N'Tumba-Byn, T.; Moison, D.; Hodroj, W.; Benjelloun, H.; Baijer, J.; Livera, J.; Frydman, R.; Benachi, A.; Habert, R. and Rouiller-Fabre, V. (2012): Cellular and molecular effect of MEHP involving LXR $\alpha$ in human fetal testis and ovary. PLoS ONE, 7 (10): e48266.

Noriega, N.C.; Howdeshell, K.L.; Furr, J.; Lambright, C.R.; Wilson, V.S. and Gray, L.E.Jr. (2009): Pubertal administration of DEHP delays puberty, suppresses testosterone production, and inhibits reproductive tract development in male SpragueDawley and Long-Evans rats. Toxicol. Sci., 111(1):163-178. 
Picard, M.; Rossier, C.; Papasouliotis, O. and Lugan, I. (2008): Bioequivalence of recombinant human FSH and recombinant human $\mathrm{LH}$ in a fixed 2:1 combination: two phase I, randomised, crossover studies. Curr. Med. Res. Opin., 24 (4): 1199-1208.

Rusyn, I.; Peters, J.M. and Cunningham, M.L. (2006): Modes of action and speciesspecific effects of di-(2ethylhexyl) phthalate in the liver. Crit. Rev. Toxicol., 36: 459-479.

Salama, R.M.; Mansour, F.K; ElSafti, F. and El-Sherif, N.M. (2013): The toxic effect of phthalate on testes of albino rats and the possible protective role of curcumin. Menoufia Med. J., 26: 23-34.

Sanbuissho, A.; Yoshida, M.; Hisada, S.; Sagami, F.; Kudo, S.; Kumazawa, T.; Ube, M.; Komatsu, S. and Ohno, Y. (2009): Collaborative work on evaluation of ovarian toxicity by repeated-dose and fertility studies in female rats. J. Toxicol. Sci., 34 (1): $1-22$.

Savchuk, I.; Soder, O. and Svechnikov, K. (2015): Monoethylhexyl phthalate stimulates androgen production but suppresses mitochondrial function in mouse leydig cells with different steroidogenic potential. Toxicol. Sci., 45: 149-56.

Schoeters, G.; Den Hond, E.; Dhooge, W.; van Larebeke, $\mathbf{N}$. and Leijs, M. (2008): Endocrine disruptors and abnormalities of pubertal development. Basic Clin. Pharmacol. Toxicol., 102: 168-
175.

Takai, R.; Hayashi, S.; Kiyokawa, J.; Iwata, Y.; Matsuo, S.; Suzuki, M.; Mizoguchi, K.; Chiba, S. and Deki, T. (2009): Collaborative work on evaluation of ovarian toxicity. Two- or four-week repeated dose studies and fertility study of di-(2-ethylhexyl) phthalate (DEHP) in female rats. J. Toxicol. Sci., 34:111-119.

Xu, C.; Chen, J.A.; Qiu, Z.; Zhao, Q.; Luo, J.; Yang, L.; Zeng, H.; Huang, Y.; Zhang, L.; Cao, J. and Shu, W. (2010): Ovotoxicity and PPAR-mediated aromatase downregulation in female spragues-dawley rats following combined oral exposure to benzo[a]pyrene and di-(2ethylhexyl( phthalate. Toxicol. Lett., 199: 323-332.

Zhang, L.D.; Li, H.C.; Chong, T.; Gao, M.; Yin, J.; Fu, D.; Deng, Q. and Wang, Z.M. (2014): Prepubertal exposure to genistein alleviates di (2-ethylhexyl) phthalate induced testicular oxidative stress in adult rats. Biomed. Res. Int., 2014: 598630.

Zhang, T.; Shen, W.; De Felici, M. and Zhang, X.F. (2016): Di (2ethylhexyl) phthalate: Adverse effects on folliculogenesis that cannot be neglected. Environ. Mol. Mutagen., 57 (8): 579-588.

Zhao, Y.; Ao, H.; Chen, L.; Sottas, C.M.; Ge, R.S.; Li, L. and Zhang, Y. (2012): Mono(2ethylhexyl) phthalate affects the steroidogenesis in rat Leydig cells through provoking ROS perturbation. Toxicol. Vitro., 26: 950-955. 
الملخص العربي

\section{الاثار السمية دون المزمنة للابي ايثيل هيكسيل فاثلات علي المبيض والخصية

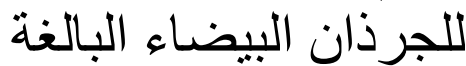

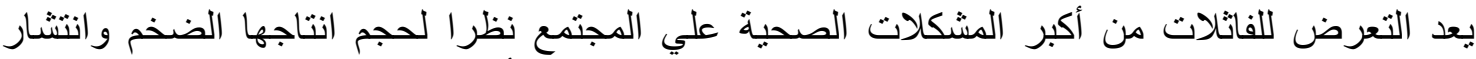

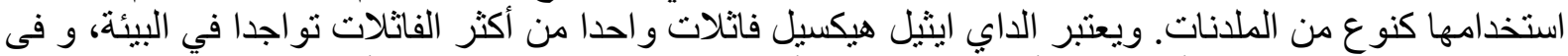

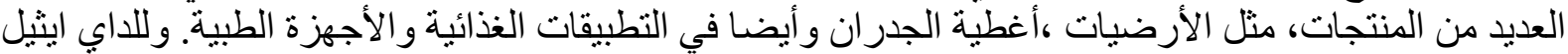

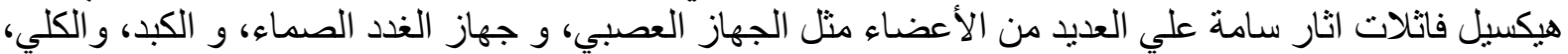

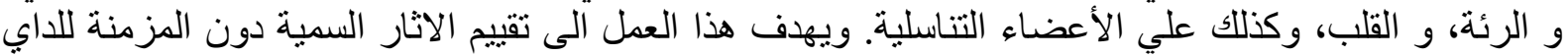

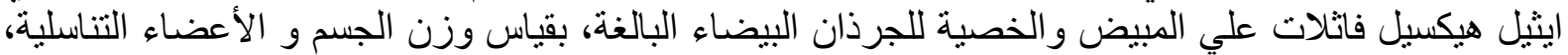

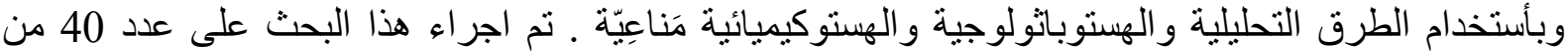

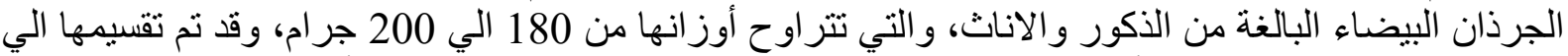

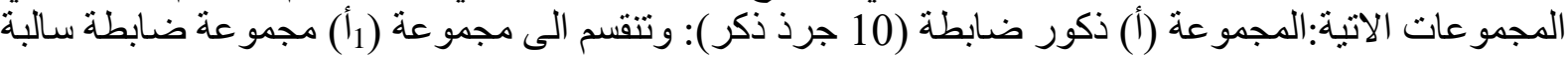

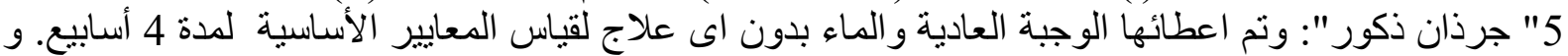

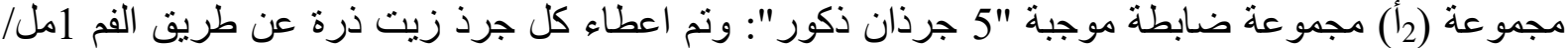

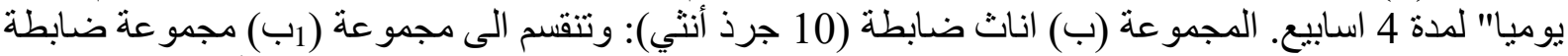

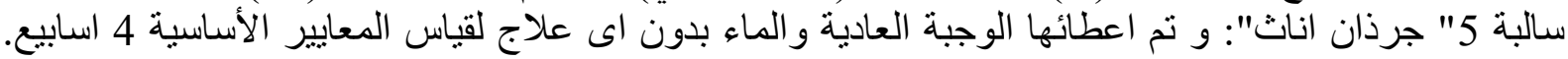

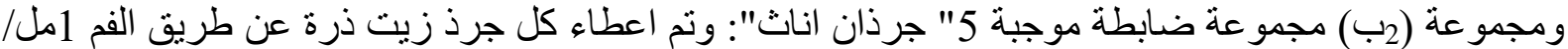

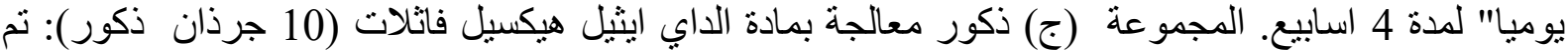

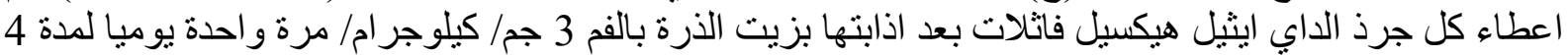

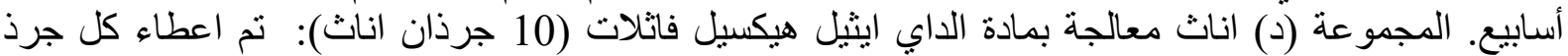

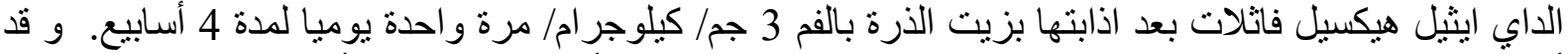

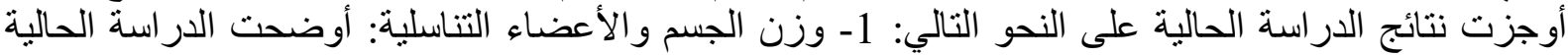

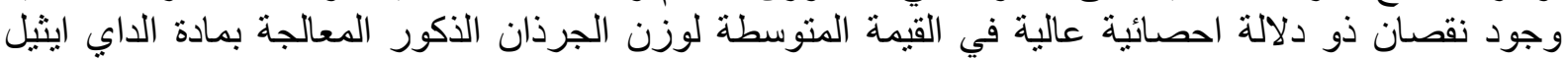

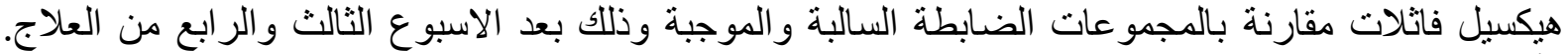

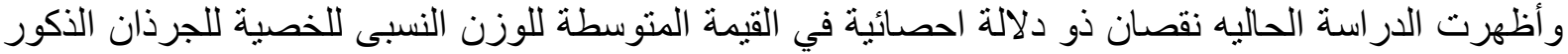

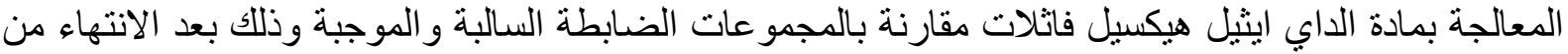

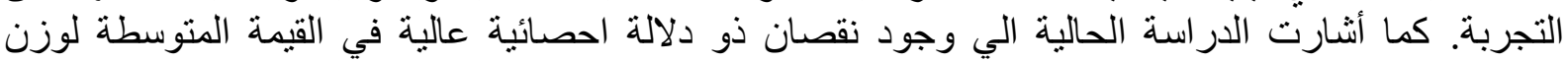

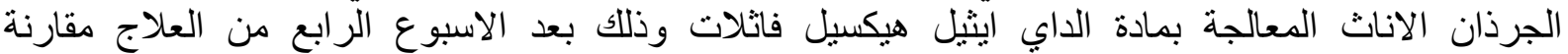

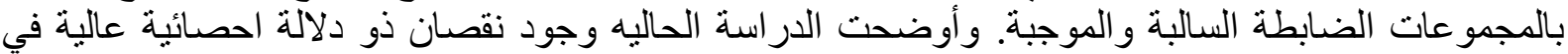

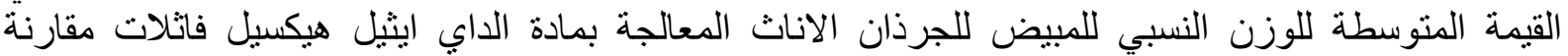

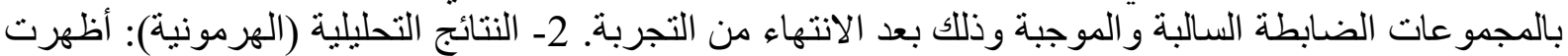

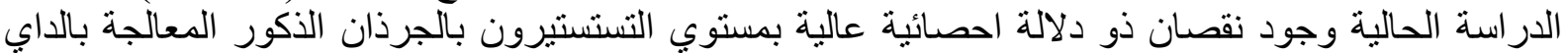

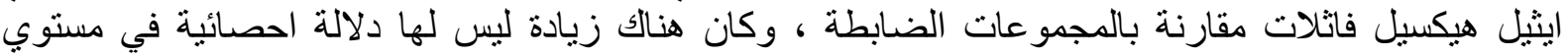

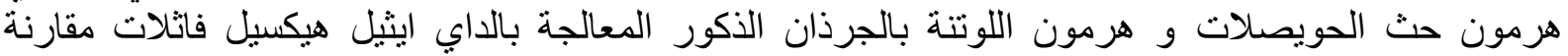

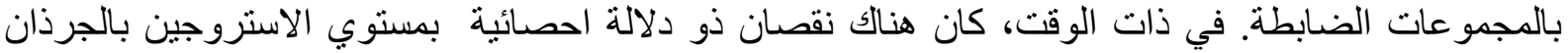

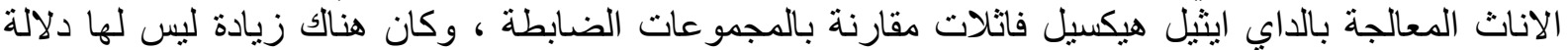

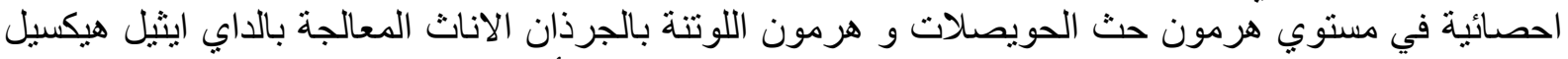

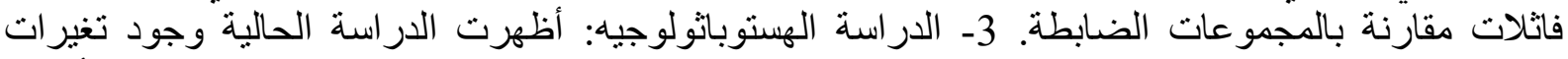

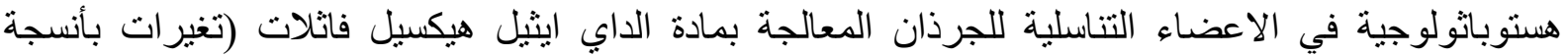

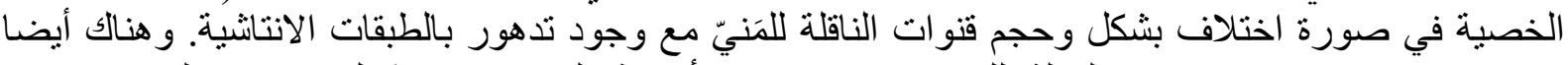

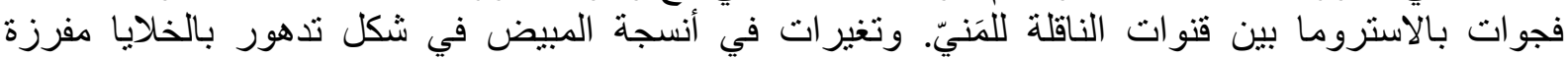

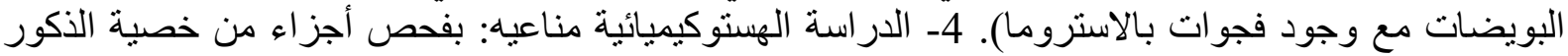
المعالجة بالداي ايثيل هيكسيل فاتلات اتضح وجود تعبير قوي لصبغة البكنا بالخلايا المولدة للنطاف فقط ووجية التود 


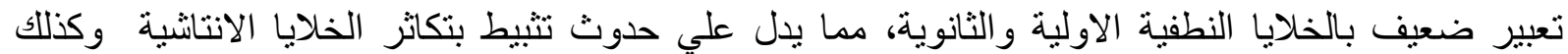

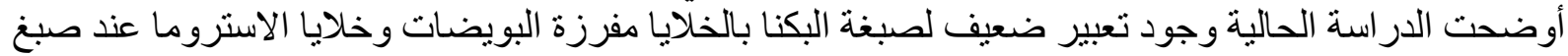

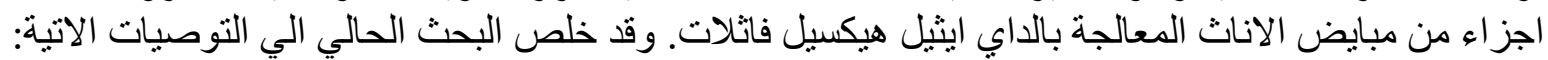

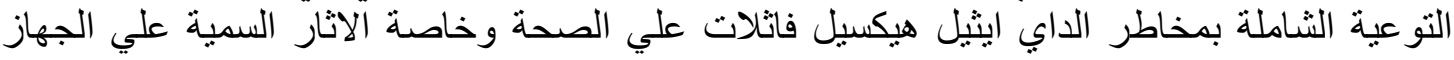

التناسلي. التقليل قدر الامكان من التعرض البيئي للاي ايثيل هيكسيل فاثلات للمحافظة علي القدرة الانجابية ،

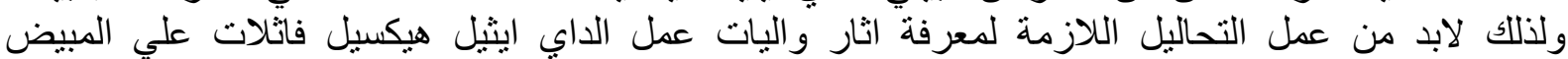
و والخصية. و أخيرا، يجب التشجيع علي استخدام بدائل أخري لهذه المادة تحترم الصحة و البيئة. 